\title{
Changes in roughness of denture base and reline materials by chemical disinfection or microwave irradiation. Surface roughness of denture base and reline materials
}

\author{
Ana Lucia MACHADO', Eunice Teresinha GIAMPAOLO', Carlos Eduardo VERGANI², Juliana Feltrin de SOUZA \\ Janaina Habib JORGE ${ }^{4}$

\begin{abstract}
1- Full Professor, Department of Dental Materials and Prosthodontics, Araraquara Dental School, UNESP - Univ. Estadual Paulista , Araraquara, SP, Brazil. 2-Associate Professor, Department of Dental Materials and Prosthodontics, Araraquara Dental School, UNESP - Univ. Estadual Paulista, Araraquara, SP, Brazil. 3- Former graduate student, Department of Dental Materials and Prosthodontics, Araraquara Dental School, UNESP - Univ. Estadual Paulista, Araraquara, SP, Brazil.

4- Associate Professor, Department of Dentistry, State University of Ponta Grossa, Ponta Grossa, PR, Brazil.
\end{abstract}

Corresponding address: Ana Lucia Machado - Departmento de Materiais Dentários e Prótese Dentária, Faculdade de Odontologia de Araraquara, UNESP R. Humaitá, n 1680 - Araraquara, SP - Brazil - 14801-903 - Phone: +55-016-33016410 - Fax: +55-016-33016406 - e-mail: cucci@foar.unesp.br

Received: October 07, 2009 - Modification: April 19, 2010 - Accepted: May 25, 2010

\section{ABSTRACT}

O bjective: The effect of disinfection by immersion in sodium perborate solution and microwave irradiation on surface roughness of one denture base resin (Lucitone 550 -L), 3 hard chairside reline resins (Tokuyama Rebase II-TR, New Truliner-NT, Ufi Gel hard$\mathrm{UH}$ ) and 3 resilient reline materials (Trusoft-T; Sofreliner-S, Dentusil-D) was evaluated. Material and methods: Thirty specimens of each material were made and divided into 3 groups: Control - not disinfected; P - daily disinfection by immersing in sodium perborate solution (3.8\%); MW - microwave disinfection ( $6 \mathrm{~min} / 650 \mathrm{~W}$ ). Roughness measurements were made after polymerization (baseline) and after 1,3 and 28 days. Roughness differences relative to the baseline readings were analyzed by Student's t-test $(P=0.05)$. Results: At baseline, Trusoft showed the highest $(P<0.001)$ mean surface roughness $(3.54 \mu \mathrm{m})$, and its surface roughness was significantly reduced after 28 days of disinfection by immersion in sodium perborate $(P=0.013)$. Roughness measurements of material Trusoft were not performed after microwave disinfection due to the severe alterations on the surface. In the 3 groups evaluated, changes in roughness were significant for materials Ufi Gel hard (from 0.11 to $0.26 \mu \mathrm{m} ; \mathrm{P} \leq 0.041)$ and New Truliner $(0.19$ to $0.76 \mu \mathrm{m} ; \mathrm{P} \leq 0.019)$. The roughness of materials Lucitone $550(0.37 \mu \mathrm{m})$, Tokuyama Rebase II $(0.37 \mu \mathrm{m})$, Sofreliner $(0.49 \mu \mathrm{m})$ and Dentusil $(0.38 \mu \mathrm{m})$ remained unaffected $(P>0.05)$. Conclusions: The roughness of the hard reline materials Ufi Gel hard and New Truliner was adversely affected by microwave disinfection, immersion in water or in sodium perborate. Microwave disinfection caused severe alterations on the surface of the resilient liner Trusoft.

Key words: Surface properties. Denture rebasing. Denture bases. Microwaves. Chemical compounds.

\section{INTRODUCTION}

Direct relining of removable dentures with hard or resilient autopolymerizing reline materials can be used as an alternative to the laboratory relining system to improve the retention and stability of the prostheses and the distribution of the masticatory forces transmitted to the underlying tissues ${ }^{14,15,18}$.

Several studies have demonstrated the adherence of Candida spp to both denture base acrylic resins and lining materials $6,7,24,29$. Candida $s p p$ has been well-established as a primary microbial factor in the etiology of denture stomatitis ${ }^{19}$. Therefore, the denture fitting-surface can act as a reservoir of Candida $s p p^{7}$ and the use of removable dentures is a predisposing factor for denture related stomatitis ${ }^{8}$. Another concern has been the continuous swallowing or aspiration of microorganisms from denture 
plaque ${ }^{21}$, which may have significant implications for the general health of the patients and in cases of immunocompromised host or medicated elderly individuals. Therefore, proper routine cleaning of the denture is essential for the prevention and treatment of denture stomatitis. Studies have shown that immersion in peroxide solutions and microwave irradiation are effective methods to inactivate plaque microorganisms from removable dentures $6,11,16,19$.

Ideally, a disinfection method should be effective without detrimental effects on the properties of the materials used for the fabrication and the relining of denture bases. Among these properties, roughness is important ${ }^{13,15,24,25}$, as rough surfaces of resilient liners and acrylic resins are significantly more prone to microorganisms accumulation and plaque formation than smooth surfaces $24,25,29$. Surface roughness provides niches in which microorganisms are protected from the shear forces and oral hygiene measures, thus allowing the entrapped microbial cells time to attach irreversibly to a surface ${ }^{23}$.

Studies have evaluated the effect of immersion solutions of the properties of denture base acrylic resins and resilient and hard relining materials, such as color ${ }^{12}$, hardness ${ }^{20}$, water sorption and solubility ${ }^{10}$ and porosity ${ }^{9}$. With regard to microwave irradiation, the studies have been focused on the effects on hardness ${ }^{15}$, bond strength to denture base resins ${ }^{15}$, flexural strength ${ }^{22}$, and residual monomer $27,28,30$. On the other hand, few studies have investigated the influence of disinfection by immersion on the surface roughness of denture base ${ }^{11}$ and reline materials ${ }^{4}$. The information on the effects of microwave disinfection on this property is even more limited ${ }^{26}$. However, considering that repeated use of a disinfection method may cause alterations on the material's surface, thus facilitating the adhesion of microorganisms, the effect of disinfection methods on the roughness of reline materials should be further investigated. In addition, the study of Bal, et al. $^{5}$ (2008) demonstrated that temporary and permanent soft lining materials showed rapid and extensive microbial colonization on the palatal surfaces of dentures carried by volunteers in vivo. Hence, attention should be paid to biofilm control in relined dentures. This is particularly important for the temporary soft liners that have been used as essential adjuncts in prosthodontic treatment and management of traumatized oral mucosa ${ }^{5}$.

The aim of this study was to evaluate the surface roughness of one denture base acrylic resin, three hard chairside reline resins and three resilient lining materials. The effect of disinfection by immersion in sodium perborate solution and microwave irradiation on this property was also evaluated. The null hypotheses were that the surface roughness of the denture base and the reline materials is similar and that both disinfection methods could be used without adverse effects on this property.

\section{MATERIAL AND METHODS}

The product names, codes, batch numbers, manufacturers, compositions, powder/liquid proportions, and polymerization/gelation conditions of the materials studied are listed in Figure 1. Thirty specimens of each material were made using a stainless steel mould with a breakaway compartment (12 $\mathrm{mm} \times 12 \mathrm{~mm} \times 2 \mathrm{~mm}$ ). When the specimens were made using the heat-polymerizing acrylic resin Lucitone 550, initially silicone impression material (ZetaPlus putty, Zhermack, Badia Polesine, Rovigo, Italy) was adapted into the stainless steel mold. The silicone patterns were then invested by sandwiching them between two glass slides in Type IV stone (Troquel Quatro, Polidental Indústria e Comércio LTDA, São Paulo, SP, Brazil), using a conventional denture processing flask. The Lucitone 550 acrylic resin was proportioned, packed under pressure, and processed according to the manufacturer's instructions (Figure 1). After polymerization, the flasks were bench cooled at room temperature for 30 min and 15 min under running water before the specimens were removed from the flasks.

To obtain the specimens of the relining resins TR, NT and UH, the materials were mixed according to the manufacturers' instructions and inserted into the mold placed on an acetate sheet and a glass slab. A second acetate sheet and glass slab was placed over the material and light pressure was applied to expel excess material from the mould. When the specimens were made using the resilient liners $T, S$ and $D$ specimens of the denture base resin $L$ were made as described. These specimens were then placed into a stainless steel mould with a breakaway compartment with $12 \mathrm{~mm} \times 12$ $\mathrm{mm} \times 4 \mathrm{~mm}$ placed on the center of a glass plate. The surfaces were treated with the bonding agents supplied by the manufacturers of each resilient liner and the remaining $2.0 \mathrm{~mm}$ was filled with the resilient liners. This thickness was selected based on the study of Murata, et al. ${ }^{17}$ (2008) which reported that, to be effective, a thickness of 1.5 to $2 \mathrm{~mm}$ of the soft liner is recommended. Material T was mixed according to the manufacturer's instructions (Figure 1 ). For the resilient liner $S$ and $D$, the specimens were made by expressing the cartridge-mixed material directly into the mold. An acetate sheet and a second glass slab were placed over the material and light pressure was applied to expel excess material from the mould. All autopolymerizing specimens were allowed to polymerize undisturbed until their polymerization/gelation.

The edges of the specimens of the denture base $\mathrm{L}$ and the hard chairside reline resins TR, NT and UH 
were carefully finished with 400-grit silicon carbide paper to remove irregularities. For the resilient liners $T, S$ and $D$, the flash was trimmed with a razor blade, and the edges were smoothed with 600-grit silicon carbide paper.

The surface roughness ( $\mathrm{Ra}-\mu \mathrm{m})$ was analyzed with a surface roughness profilometer (Mitutoyo surftest SJ-401, Mitutoyo Corporation, Tokyo, Japan) with a diamond stylus (tip radius $5 \mu \mathrm{m}$ ). A reading was obtained by the needle passing across $0.8 \mathrm{~mm}$ length at $1 \mathrm{~mm} / \mathrm{s}$ to the nearest of 0.01 $\mu \mathrm{m}$. This procedure was repeated two more times at the same position for a total of three readings. As surface roughness was measured at four positions, radially across each specimen, a final $\mathrm{Ra}$ average was calculated and the means of individual specimens were averaged (baseline reading). An orientation jig was fabricated to position the stylus of the profilometer instrument to the same location on the specimen for repeated measurements ${ }^{4}$.

For the autopolymerizing reline materials, the roughness measurements were performed within the first hour in dry condition at room temperature $\left(23 \pm 2^{\circ} \mathrm{C}\right)$. These values were used as controls due to the fact that the patients will be wearing the relined denture bases soon after polymerization, without any effect of water sorption and disinfection. For the resin $L$, the specimens were stored in distilled water at $37 \pm 2^{\circ} \mathrm{C}$ for 48 hours before roughness measurements. This time was used as representative of the time elapsed between relining procedure and denture insertion, when laboratory-processed reline system is performed ${ }^{4}$. During this waiting time, the dentures should be immersed in water.

Thereafter, the specimens of each material $(n=30)$ were divided into three groups, according to the following experimental conditions:

$\mathrm{C}=$ specimens were not submitted to the disinfection procedures, but kept in water at $37 \pm 2^{\circ} \mathrm{C}$ for 4 weeks (control).

$\mathrm{P}=$ specimens were submitted to daily disinfection by immersing into $3.8 \%$ sodium perborate solution at $50^{\circ} \mathrm{C}$ for 8 hours at room temperature, and immersed into distilled water for the remainder of the $24 \mathrm{~h}$ period at $37^{\circ} \mathrm{C}$, thus simulating an overnight daily soaking ${ }^{13}$. For each immersion, fresh sodium perborate solution was prepared and the distilled water was changed daily. This cycle was repeated up to 4 weeks, so that the

\begin{tabular}{|c|c|c|c|c|c|c|}
\hline Product & Code & Manufacturer & $\begin{array}{l}\text { Powder/liquid } \\
\text { ratio }\end{array}$ & Composition & $\begin{array}{l}\text { Batch } \\
\text { number }\end{array}$ & $\begin{array}{l}\text { Polymerization/ } \\
\text { gelation } \\
\text { conditions }\end{array}$ \\
\hline $\begin{array}{l}\text { Tokuyama } \\
\text { Rebase II }\end{array}$ & TR & $\begin{array}{l}\text { Tokuyama Dental } \\
\text { Corp., Tokyo, Japan }\end{array}$ & $2.056 \mathrm{~g} / 1 \mathrm{~mL}$ & $\begin{array}{l}\text { Powder - PEMA } \\
\text { Liquid - AAEM and } \\
\text { 1,9-nonanediol } \\
\text { dimethacrylate }\end{array}$ & UF62694 & $\begin{array}{c}8 \mathrm{~min} \\
\text { at room } \\
\text { temperature }\end{array}$ \\
\hline New Truliner & NT & $\begin{array}{c}\text { The Bosworth Co., } \\
\text { Skokie, IL, USA }\end{array}$ & $1.34 \mathrm{~g} / 1 \mathrm{~mL}$ & $\begin{array}{c}\text { Powder - PEMA } \\
\text { Liquid - IBMA and DBP }\end{array}$ & 0409-495 & $\begin{array}{l}10-15 \text { min at } \\
\text { room temperature }\end{array}$ \\
\hline Ufi Gel hard & $\mathrm{UH}$ & $\begin{array}{l}\text { Voco, Cuxhaven, } \\
\text { Germany }\end{array}$ & $2.12 \mathrm{~g} / 1.2 \mathrm{~mL}$ & $\begin{array}{c}\text { Powder - PEMA } \\
\text { Liquid - 1,6-HDMA }\end{array}$ & 571845 & $\begin{array}{l}7 \text { min at room } \\
\text { temperature }\end{array}$ \\
\hline Trusoft & $\mathrm{T}$ & $\begin{array}{c}\text { The Bosworth Co., } \\
\text { Skokie, IL, USA }\end{array}$ & $1.06 \mathrm{~g} / 1 \mathrm{~mL}$ & $\begin{array}{c}\text { Powder - PEMA } \\
\text { Liquid - Alkyl phthalate } \\
\text { (plasticizer) and ethyl } \\
\text { alcohol }\end{array}$ & 0403-163 & $\begin{array}{l}5 \text { min at room } \\
\text { temperature }\end{array}$ \\
\hline Sofreliner & $S$ & $\begin{array}{l}\text { Tokuyama Dental } \\
\text { Corp., Tokyo, Japan }\end{array}$ & $\begin{array}{c}\text { Auto-dispensing } \\
\text { system }\end{array}$ & $\begin{array}{c}\text { Polyorganosiloxane } \\
\text { Silicone resin powder } \\
\text { Silica }\end{array}$ & U684606 & $\begin{array}{l}6.5 \text { min at room } \\
\text { temperature }\end{array}$ \\
\hline Dentusil & D & $\begin{array}{c}\text { The Bosworth Co., } \\
\text { Skokie, IL, USA }\end{array}$ & $\begin{array}{c}\text { Auto-dispensing } \\
\text { system }\end{array}$ & $\begin{array}{l}\text { Polyorganosiloxane } \\
\text { Silica } \\
\end{array}$ & 702.073 & $\begin{array}{l}5 \mathrm{~min} \text { at room } \\
\text { temperature }\end{array}$ \\
\hline $\begin{array}{l}\text { Lucitone } \\
550\end{array}$ & $L$ & $\begin{array}{l}\text { Dentsply Indústria } \\
\text { e Comércio Ltda., } \\
\text { Petrópolis, RJ, } \\
\text { Brazil }\end{array}$ & $2.1 \mathrm{gm} / 1 \mathrm{~mL}$ & $\begin{array}{c}\text { Powder - PMMA } \\
\text { Liquid - MMA and } \\
\text { EDGMA }\end{array}$ & $\begin{array}{c}P-303758 \\
L-59244\end{array}$ & $\begin{array}{l}90 \text { min at } 73^{\circ} \mathrm{C} \\
\text { and then } 100^{\circ} \mathrm{C} \\
\text { boiling water for } \\
30 \text { min }\end{array}$ \\
\hline
\end{tabular}

PEMA, poly (ethyl methacrylate); AAEM - 2-acetoacetoxy (ethyl) methacrylate; PMMA, poly (methyl methacrylate); IBMA, isobutyl methacrylate; DBP, di-n-butyl phthalate; 1,6-HDMA, 1,6-hexanediol dimethacrylate; MMA, (methyl methacrylate); EDGMA, (ethylene glycol dimethacrylate)

Figure 1- Materials used in this study 
period of chemical disinfection would be comparable with that of microwave disinfection and control.

$\mathrm{MW}=$ specimens were submitted to microwave disinfection (6 $\mathrm{min} / 650 \mathrm{~W}$ ), with the specimens immersed in $200 \mathrm{~mL}$ of water during irradiation. The irradiations were performed three times a week for a total of four weeks ${ }^{19}$. The specimens were stored in water at $37^{\circ} \mathrm{C}$ between disinfection cycles.

For groups C and MW, the water was changed daily. For all groups, the specimens were individually placed in $500-\mathrm{mL}$ beakers and the volume of liquid (distilled water or perborate solution) used was $200 \mathrm{~mL}$. This minimum volume was calculated by measuring the volume of liquid that would completely cover a maxillary complete denture in a standard denture pot ${ }^{20}$.

The surface roughness of each specimen was measured again at 1, 3 and 28 days, using the same procedures described above. For each material, the differences between the roughness values obtained in each period and the baseline reading was then calculated and used to evaluate the changes in roughness due to the disinfection procedures or immersion in water. Baseline roughness values were analyzed by Kruskal-Wallis test to determine differences among materials. For each material, the changes in roughness (differences between the roughness values obtained in each period and the baseline reading) at the different time intervals within each group were analyzed statistically using Student's t-test. Statistical analyses were conducted at $95 \%$ level of confidence.

\section{RESULTS}

Table 1 shows the mean surface roughness values recorded at baseline and standard deviations, and

Table 1- Mean baseline roughness $(\mathrm{Ra}-\mu \mathrm{m})$ and standard deviations (SD) for all materials evaluated

\begin{tabular}{cc}
\hline Material & Mean (SD) \\
\hline New Truliner (NT) & $0.22 \pm 0.12^{\mathrm{a}}$ \\
\hline Ufi Gel hard (UH) & $0.23 \pm 0.12^{\mathrm{ab}}$ \\
\hline Lucitone (L) & $0.37 \pm 0.19^{\mathrm{bc}}$ \\
\hline Tokuyama Rebase II (TR) & $0.37 \pm 0.19^{\mathrm{bc}}$ \\
\hline Dentusil (D) & $0.38 \pm 0.22^{\mathrm{bc}}$ \\
\hline Sofreliner (S) & $0.49 \pm 0.17^{\mathrm{c}}$ \\
\hline Trusoft (T) & $3.54 \pm 0.48^{\mathrm{d}}$ \\
\hline
\end{tabular}

Means with identical letter were not significantly different (Kruskal-Wallis; P>.05).

Table 2- Means (SD) roughness differences relative to the baseline readings

\begin{tabular}{|c|c|c|c|c|c|c|c|}
\hline Material & Group & $1^{\text {st }}$ day & & $3^{\text {rd day }}$ & & $28^{\text {th }}$ day & \\
\hline \multirow[t]{3}{*}{ NT } & Water (C) & $-0.01 \pm 0.17$ & & $0.27 \pm 0.27$ & * & $0.19 \pm 0.20$ & * \\
\hline & Perborate $(\mathrm{P})$ & $0.32 \pm 0.19$ & * & $0.32 \pm 0.11$ & * & $0.42 \pm 0.14$ & * \\
\hline & Microwave (MW) & $0.52 \pm 0.13$ & * & $0.56 \pm 0.12$ & * & $0.76 \pm 0.22$ & * \\
\hline \multirow[t]{3}{*}{ TR } & Water (C) & $0.02 \pm 0.23$ & & $0.06 \pm 0.30$ & & $0.03 \pm 0.31$ & \\
\hline & Perborate $(P)$ & $0.06 \pm 0.21$ & & $0.13 \pm 0.34$ & & $0.24 \pm 0.33$ & \\
\hline & Microwave (MW) & $0.13 \pm 0.24$ & & $0.07 \pm 0.13$ & & $0.14 \pm 0.28$ & \\
\hline \multirow[t]{3}{*}{$\mathrm{UH}$} & Water (C) & $0.26 \pm 0.32$ & * & $0.21 \pm 0.27$ & * & $0.19 \pm 0.20$ & * \\
\hline & Perborate $(\mathrm{P})$ & $-0.02 \pm 0.20$ & & $0.11 \pm 0.14$ & * & $0.25 \pm 0.26$ & * \\
\hline & Microwave (MW) & $0.17 \pm 0.07$ & * & $0.18 \pm 0.12$ & * & $0.14 \pm 0.13$ & * \\
\hline \multirow[t]{3}{*}{ L } & Water (C) & $0.08 \pm 0.12$ & & $0.03 \pm 0.12$ & & $0.08 \pm 0.12$ & \\
\hline & Perborate $(P)$ & $0.08 \pm 0.08$ & & $0.04 \pm 0.06$ & & $0.09 \pm 0.12$ & \\
\hline & Microwave (MW) & $0.08 \pm 0.22$ & & $0.00 \pm 0.21$ & & $0.07 \pm 0.18$ & \\
\hline \multirow[t]{3}{*}{$S$} & Water $(C)$ & $-0.01 \pm 0.07$ & & $-0.04 \pm 0.20$ & & $-0.10 \pm 0.16$ & \\
\hline & Perborate $(\mathrm{P})$ & $0.02 \pm 0.05$ & & $0.03 \pm 0.17$ & & $0.06 \pm 0.31$ & \\
\hline & Microwave (MW) & $0.00 \pm 0.11$ & & $-0.07 \pm 0.22$ & & $0.00 \pm 0.21$ & \\
\hline \multirow[t]{3}{*}{ D } & Water (C) & $-0.07 \pm 0.21$ & & $0.06 \pm 0.25$ & & $0.10 \pm 0.29$ & \\
\hline & Perborate $(\mathrm{P})$ & $-0.10 \pm 0.25$ & & $-0.08 \pm 0.24$ & & $-0.11 \pm 0.28$ & \\
\hline & Microwave (MW) & $0.20 \pm 0.35$ & & $0.19 \pm 0.37$ & & $0.14 \pm 0.37$ & \\
\hline \multirow[t]{2}{*}{$\mathrm{T}$} & Water (C) & $-0.67 \pm 0.68$ & * & $-0.86 \pm 0.65$ & * & $-0.75 \pm 0.46$ & * \\
\hline & Perborate $(P)$ & $0.10 \pm 0.40$ & & $0.08 \pm 0.54$ & & $-0.43 \pm 0.44$ & * \\
\hline
\end{tabular}

* Statistical difference between the roughness measurements obtained at three evaluation periods (1, 3 and 28 days) and the baseline readings (t-Student test; $\mathrm{P}<.05$ ). 
the results from the Kruskal-Wallis test. At baseline, the resilient liner material $T$ showed the highest mean surface roughness. Material S exhibited significantly higher surface roughness than the hard chairside reline resins NT and UH $(P<0.001)$,

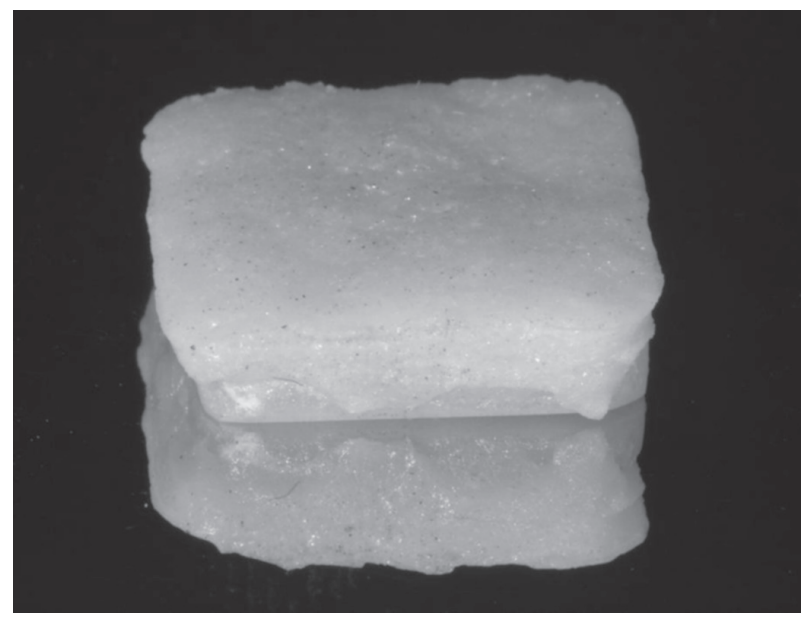

Figure 2- Trusoft material after microwave disinfection

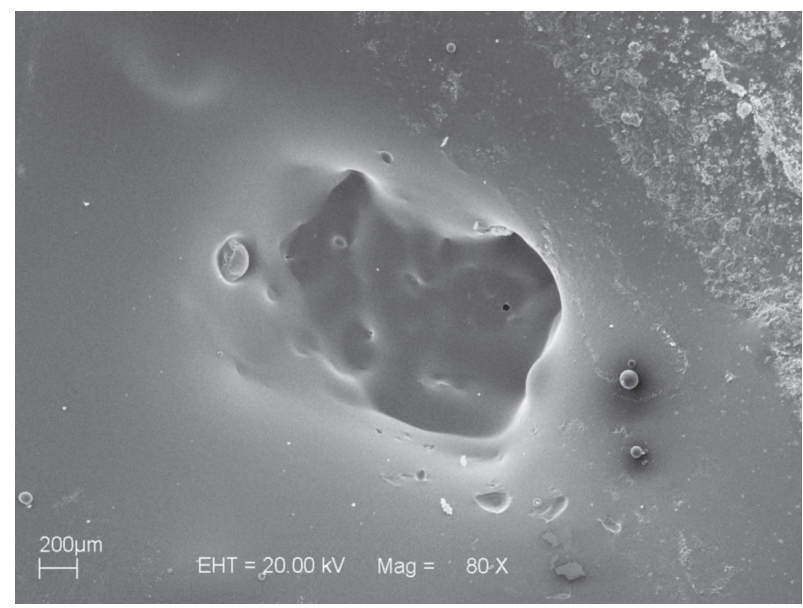

Figure 3-Scanning electron microscopy (SEM) micrograph of material Trusoft after microwave disinfection

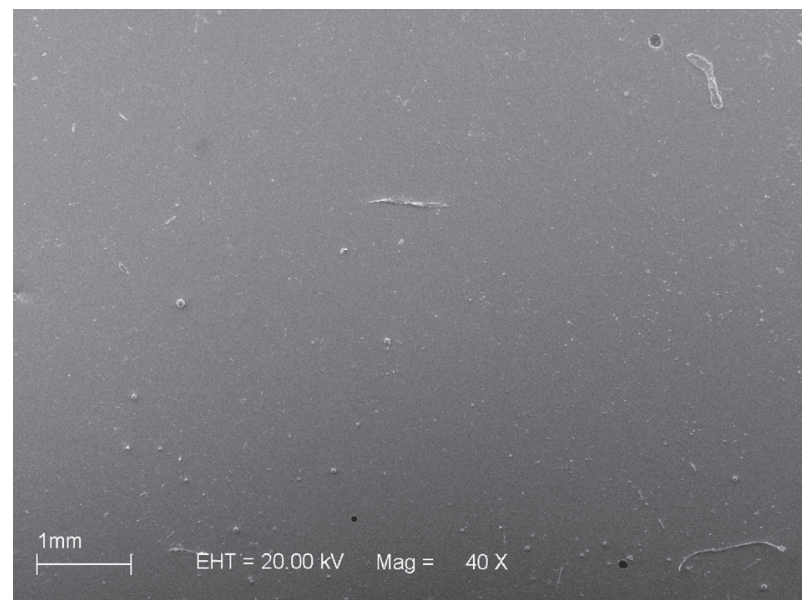

Figure 4- Scanning electron microscopy (SEM) micrograph of material Sofreliner after microwave disinfection which were not significantly different from each other $(P=1.00)$. No significant differences were found among $\mathrm{UH}, \mathrm{TR}, \mathrm{D}$ and $\mathrm{L}$, and among $T R, \mathrm{~L}$, $\mathrm{D}$ and $\mathrm{S}(P>0.05)$.

Table 2 shows the results from the t-Student test for the analysis of the differences between the roughness measurements obtained at three evaluation periods ( 1,3 and 28 days) and the baseline readings, for the three groups analyzed in this study. No significant changes in roughness were found for the materials TR, L, S and D during the 28 days, regardless of experimental condition evaluated $(P>0.05)$. The resilient liner T presented significant decrease in roughness after the first day of immersing in water $(P=0.019)$. The decrease in roughness was greater in the $3(P=0.004)$ and 28 days periods $(P=0.001)$. When immersed in sodium perborate solution, material $\mathrm{T}$ also showed a decrease in roughness; however, this decrease was significant in comparison to the baseline reading only after 28 days of immersion ( $P=0.013)$. The hard reline resin NT also showed significant changes in roughness. In the control group, significant increase in roughness was observed at the $3(P=0.018)$ and 28 days periods $(P=0.019)$. For the disinfected specimens, significant changes in roughness were found after the first day of disinfection by immersing into sodium perborate solution $(P=0.001)$ or microwave irradiation $(P<0.001)$. A significant increase in roughness of material NT was also observed at the 3 and 28 days periods $(P<0.001)$. The reline resin $\mathrm{UH}$ also exhibited significantly increased roughness when immersed in water for 1,3 and 28 days ( $P=0.030$; $P=0.041 ; P=.014$; respectively), and in sodium perborate solution for $3(P=0.039)$ and 28 days $(P=0.019)$. When subjected to disinfection by microwave irradiation, the changes in roughness of UH specimens observed at the $1(P<0.001)$ and 3 -days $(P=0.002)$ were higher than that of the 28 -days period $(P=0.015)$. Figure 2 shows Trusoft material after microwave disinfection, and Figures 3 and 4 illustrate the scanning electron microscopy (SEM) of the materials Trusoft and Sofreliner after microwave disinfection, respectively. It can be seen from Figures 2 and 3, that microwaving produced severe alterations on the surface of the material $\mathrm{T}$, which impeded roughness measurements after this procedure.

\section{DISCUSSION}

Surface roughness is an important property due to its influence on microbial adhesion ${ }^{23,24,29}$. The adherence of microorganisms on the surface of polymeric materials, such as denture base acrylic resins and hard and resilient liners, is the first step for the colonization and development of an oral 
infection in denture wearers ${ }^{24}$. Therefore, these materials should present the smoothest surfaces possible in order to prevent biofilm formation and oral mucosa inflammation and facilitate denture cleansing 23-25,29.

The results of the present study demonstrated that the hard reline materials presented similar (TR and UH) or lower (NT) mean initial surface roughness values compared to those of the denture base acrylic resin $\mathrm{L}$. These findings may be related to the fact that the denture base and hard reline materials were processed against glass following the recommendation of Radford, et al. ${ }^{25}$ (1998) who stated that control surfaces must be as smooth as possible. With regard the resilient lining materials, there were no significant differences between the mean values obtained for $S$ and $D$ and those obtained for L. However, T presented the highest initial roughness mean value (Table 1 ). Thus, the first null hypothesis was rejected. The manner how the resilient relining materials evaluated in this study are supplied could help explain the differences observed in their surface roughness. While material $T$ is supplied as separate powder and liquid components that should be mixed, S and D soft liners are automatically mixed and extruded using the dual paste cartridge and dispenser system. It is possible that air bubbles incorporated to the material during mixing were clustered close to the surface, contributing to the higher roughness of $\mathrm{T}$ compared to the other resilient relining materials. Conversely, the use of cartridge and dispenser system probably prevented bubble formation within the $S$ and $D$ specimens and on their surface.

The second null hypothesis that both disinfection methods could be used without adverse effects on the surface roughness of the materials was also rejected. The results showed that the relining resilient materials had different behaviors when subjected to disinfection methods evaluated, which is in agreement with the findings of previous investigations $^{13}$. In the present study, the surface roughness of $S$ and $D$ materials remained unaltered regardless of the experimental conditions (Figure 4). On the other hand, the soft liner $T$ showed $a$ significant decrease in surface roughness when immersed in water and the differences compared to the initial roughness mean value (baseline reading) were more pronounced after longer immersion periods (Table 2). A decrease in surface roughness was also observed after disinfection with $3.8 \%$ sodium perborate, though it was less pronounced and occurred only after 28 days of immersion. Microwaving of $T$ produced severe alterations on the material's surface, which impeded roughness measurements after this procedure (Figures 2 and 3 ). The different behaviors of the resilient relining materials may be partially explained by the differences in their compositions. $\mathrm{T}$ is a plasticized acrylic resin, which, according to its manufacturer, presents a poly(ethylmethacrylate)-based powder component and a liquid component with high concentration of a plasticizing agent (alkyl phthalate) and ethanol. Therefore, it is likely that the presence of the plasticizing agent in its composition and the viscoelastic behavior of plasticized resins ${ }^{18}$ allowed the material to flow over time when immersed in water. It may be considered that this flow permitted the filling of porosities, irregularities and possible depressions formed on acrylic surface, resulting in lower roughness mean values ${ }^{9}$. In addition, two phenomena take place when plasticized resins are immersed in water: loss of plasticizing agent and water sorption ${ }^{14,18}$. If the sorption of water by the relining material $T$ was greater than the loss of plasticizing agent, a volume increase might have occurred, making the surface smoother ${ }^{14}$. When material $\mathrm{T}$ was immersed in the sodium perborate solution, surface roughness also decreased, but more slowly (28 days; Table 2 ). It is likely that the higher ionic concentration in the sodium perborate solution compared to water resulted in greater release of soluble components ${ }^{14}$. However, the water sorption and solubility of this material when subjected to the same conditions evaluated in the present study should be further investigated to confirm these hypotheses. The severe alterations observed on the surface of $T$ specimens when disinfected by microwave irradiation may be related to the temperature. During microwaving, the water in which the materials are immersed reached the boiling temperature after approximately 1 minute and 30 seconds and remained at this temperature up to the end of the microwaving cycle. It is possible that the heating of $T$ during microwave disinfection has favored the diffusion and release of soluble components and accelerated the aging process ${ }^{1}$. Conversely, in silicone-based relining materials, such as $\mathrm{S}$ and $\mathrm{D}$ (polyorganosiloxanes), the polymer is an elastomer and does not need external plasticizing agents ${ }^{15}$. Furthermore, the polymer chains in $S$ and $D$ are formed by addition reaction and thus no byproduct is formed ${ }^{18}$. It has been demonstrated that silicone-based resilient materials polymerized by addition reaction remain stable during water storage for long periods ${ }^{18}$. Therefore, the lack of significant effects of the disinfection methods on the surface roughness of $S$ and $D$ may be partially attributed to the favorable characteristics of water sorption and solubility of these resilient relining materials. Jin, et al. ${ }^{13}$ (2003) have also found that, in general, silicone-based resilient materials were more stable regarding surface roughness and color change than the plasticized resins.

Concerning the hard reline materials, the most significant alterations were observed for 
NT. Among the hard relining materials evaluated in this study, NT has the highest liquid/powder mixing ratio, and this might have resulted in the presence of a larger number of residual monomer molecules in the polymerized resin ${ }^{28}$. In addition, NT also presents a plasticizing agent (di-n-butyl phthalate) in its composition ${ }^{27}$. The release of these residual monomer molecules and the plasticizing agent might have contributed to alter the surface characteristics of the material, increasing its surface roughness. This release might have been facilitated by the ionic concentration of the sodium perborate solution ${ }^{14}$ and by the temperature of the water during microwave disinfection ${ }^{27}$, which could partially explain the more significant alterations observed after use of both disinfection methods compared to the control (immersion water).

The results also showed that the surface roughness of the denture base acrylic resin $L$ and the hard reline material TR was not affected by their immersion in water and neither by the disinfection methods evaluated in this study. These results are similar to those reported by Harrison, et al. ${ }^{11}$ (2004), and may be related to the type of polymerization of the materials. Heat-polymerized materials, such as $L$, present a higher monomer-to-polymer conversion rate and lower residual monomer content ${ }^{27,28}$. Although the hard reline TR material is an autopolymerized resin, it contains the monomer 2-acetoacetoxyethyl methacrylate, which has been used in experimental materials to increase the polymerization rate due to its molecular structure and higher reactivity ${ }^{30}$. This monomer presents a longer lateral chain and several reactive centers, which provide a more complete polymerization. In addition, L and TR contain crosslinking agents in their compositions (ethylene glycol dimethacrylate and 1,9-nonanediol dimethacrylate, respectively), which may have contributed to the formation of more dense and stable polymer structures ${ }^{2,3}$. This may have contributed to the absence of significant effect on the surface roughness of these materials after immersion in water or disinfection.

The alterations observed in the surface roughness of the reline resin UH were not expected because this material also has a high concentration of the crosslinking agent 1,6-hexanediol dimethacrylate. Due to the greater distance between the methacrylate groups, this crosslinking agent also presents a more reactive second group ${ }^{27,28}$, thus favoring the monomer-to-polymer conversion. Nevertheless, it has been demonstrated that UH material showed significantly higher residual monomer content and release than a reline resin with similar composition (Tokuso Rebase Fast) $^{28}$.

The goal of subjecting dentures to disinfection by immersion in a sodium perborate solution or microwave irradiation is controlling the biofilm formed on the acrylic surface. Nevertheless, if the repeated use of a disinfection method causes significant alterations on the material's surface, this goal is not achieved because the increase in the surface roughness may favor the adhesion of microorganisms. It is important to emphasize, however, that the influence of the changes in surface roughness observed in the present study on the adherence of microorganisms to the reline materials was not investigated. In addition, surface roughness is not the only factor involved in the adhesion of microorganisms to polymer-based materials ${ }^{21}$. The presence of salivary pellicle and the surface free energy have been also reported to influence the adhesion of microorganisms ${ }^{23}$. Others factors such as wettability, hydrophobicity and electrostatic interactions of materials used in prosthodontics may also influence the microbial retention ${ }^{29}$. These are limitations of the present study and should be considered in further investigations. Despite these limitations, the findings presented here demonstrated that immersion in sodium perborate and microwave irradiation may not be seen as a general recommendation for denture disinfection, since it may increase the surface roughness of some materials used for relining dentures, as observed previously ${ }^{6}$. This may help dental practitioners instructing their patients regarding the most effective methods for biofilm control, according to the type of relining material used in their dentures.

\section{CONCLUSION}

Within the limitations of this study the following conclusions were drawn:

In all conditions evaluated, the resilient relining material T presented the highest surface roughness mean values.

There were no significant differences in the surface roughness of the denture base resin $L$ and the relining materials $T R, S$ and $D$ under the conditions evaluated.

$\mathrm{T}$ presented a significant decrease in surface roughness after immersion in water or in a $3.8 \%$ sodium perborate solution; microwave disinfection caused severe alterations on the surface of this material.

NT and UH reline resins showed significant increase of surface roughness after immersion in water or disinfection, and more pronounced effects were observed for New Truliner after microwave disinfection.

\section{ACKNOWLEDGEMENTS}

This investigation was supported by São Paulo State Research Foundation - FAPESP (Grant 2003/06313-9). 


\section{REFERENCES}

1- Al-Athel M, Jagger R, Jagger D. Effect of ageing on the bond strength of a permanent denture soft lining material. J Oral Rehabil. 2002;29:992-6.

2- Arima T, Murata $\mathrm{H}$, Hamada T. The effects of cross-linking agents on the water sorption and solubility characteristics of denture base resin. J Oral Rehabil. 1996;23:476-80.

3- Arima T, Murata H, Hamada T. Properties of highly crosslinked autopolymerizing reline acrylic resins. J Prosthet Dent. 1995;73:55-9.

4- Azevedo A, Machado AL, Vergani CE, Giampaolo ET, Pavarina AC, Magnani R. Effect of disinfectants on the hardness and roughness of reline acrylic resins. J Prosthodont. 2006;15:235-42.

5- Bal BT, Yavuzyilmaz H, Yücel M. A pilot study to evaluate the adhesion of oral microorganisms to temporary soft lining materials. J Oral Sci. 2008;50:1-8.

6- Banting DW, Hill SA. Microwave disinfection of dentures for the treatment of oral candidiasis. Spec Care Dentist. 2001;21:4-8.

7- Brosky ME, Pesun IJ, Morrison B, Hodges JS, Lai JH, Liljemark W. Clinical evaluation of resilient denture liners. Part 2: Candida count and speciation. J Prosthodont. 2003;12:162-7.

8- Dar Odeh NS, Shehabi AA. Oral candidosis in patients with removable dentures. Mycoses. 2003;46:187-91.

9- Davenport JC, Wilson HJ, Basker RM. The compatibility of tissue conditioners with denture cleaners and chlorhexidine. J Dent. 1978;6:239-46.

10- Dinçkal Yanikoglu N, Yeşil Duymuş Z. Comparative study of water sorption and solubility of soft lining materials in the different solutions. Dent Mater J. 2004;23:233-9.

11- Harrison Z, Johnson A, Douglas CW. An in vitro study into the effect of a limited range of denture cleaners on surface roughness and removal of Candida albicans from conventional heat-cured acrylic resin denture base material. J Oral Rehabil. 2004;31:460-7. 12- Hong G, Murata H, Li Y, Sadamori S, Hamada T. Influence of denture cleansers on the color stability of three types of denture base acrylic resin. J Prosthet Dent. 2009;101:205-13.

13- Jin C, Nikawa H, Makihira S, Hamada T, Furukawa M, Murata H. Changes in surface roughness and colour stability of soft denture lining materials caused by denture cleansers. J Oral Rehabil. 2003;30:125-30.

14- Kazanji MN, Watkinson AC. Soft lining materials: their absorption of, and solubility in, artificial saliva. $\mathrm{Br}$ Dent $\mathrm{J}$. 1988;165:91-4.

15- Machado AL, Breeding LC, Puckett A. Effect of microwave disinfection on the hardness and adhesion of two resilient liners. J Prosthet Dent. 2005;94:183-9.

16- McCabe JF, Murray ID, Kelly PJ. The efficacy of denture cleansers. Eur J Prosthodont Restor Dent. 1995;3:203-7.

17- Murata H, Hamada T, Sadamori S. Relationship between viscoelastic properties of soft denture liners and clinical efficacy. Japan Dental Sci Rev. 2008;44:128-32.
18- Murata H, Taguchi N, Hamada T, McCabe JF. Dynamic viscoelastic properties and the age changes of long-term soft denture liners. Biomaterials. 2000;21:1421-7.

19- Neppelenbroek KH, Pavarina AC, Palomari Spolidorio DM, Sgavioli Massucato EM, Spolidorio LC, Vergani CE. Effectiveness of microwave disinfection of complete dentures on the treatment of Candida-related denture stomatitis. J Oral Rehabil. 2008;35:83646.

20- Neppelenbroek KH, Pavarina AC, Vergani CE, Giampaolo ET. Hardness of heat-polymerized acrylic resins after disinfection and long-term water immersion. J Prosthet Dent 2005;93:171-6. 21- Nikawa H, Jin C, Makihira S, Egusa H, Hamada T, Kumagai $\mathrm{H}$. Biofilm formation of Candida albicans on the surfaces of deteriorated soft denture lining materials caused by denture cleansers in vitro. J Oral Rehabil. 2003;30:243-50.

22- Pavarina AC, Neppelenbroek KH, Guinesi AS, Vergani CE, Machado AL, Giampaolo ET. Effect of microwave disinfection on the flexural strength of hard chairside reline resins. J Dent. 2005;33:741-8.

23- Quirynen M, Bollen CM. The influence of surface roughness and surface-free energy on supra- and subgingival plaque formation in man: a review of the literature. J Clin Periodontol. 1995;22:1-14. 24- Radford DR, Challacombe SJ, Walter JD. Denture plaque and adherence of Candida albicans to denture-base materials in vivo and in vitro. Cr Rev Oral Biol Med. 1999;10:99-116.

25- Radford DR, Sweet SP, Challacombe SJ, Walter JD. Adherence of Candida albicans to denture-base materials with different surface finishes. J Dent. 1998;26:577-83.

26- Sartori EA, Schmidt CB, Walber LF, Shinkai RSA. Effect of microwave disinfection on denture base adaptation and resin surface roughness. Braz Dent J. 2006;17:195-200.

27- Urban VM, Machado AL, Oliveira RV, Vergani CE, Pavarina $A C$, Cass QB. Residual monomer of reline acrylic resins. Effect of water-bath and microwave post-polymerization treatments. Dent Mater. 2007;23:363-8.

28- Urban VM, Machado AL, Vergani CE, Giampaolo ET, Pavarina AC, Almeida FG, et al. Effect of water-bath post-polymerization on the mechanical properties, degree of conversion, and leaching of residual compounds of hard chairside reline resins. Dent Mater. 2009;25:662-71.

29- Verran J, Maryan CJ. Retention of Candida albicans on acrylic resin and silicone of different surface topography. J Prosthet Dent. 1997;77:535-9.

30- Viljanen EK, Langer S, Skrifvars M, Vallittu PK. Analysis of residual monomers in dendritic methacrylate copolymers and composites by HPLC and headspace-GC/MS. Dent Mater. 2006;9:845-51. 